\title{
Pitfalls of genetic counselling in Pfeiffer's syndrome
}

\author{
M BARAITSER,* MARY BOWEN-BRAVERY, AND P SALDAÑ-GARCIA \\ From the Kennedy-Galton Centre for Clinical Genetics, Harperbury Hospital, Harper Lane, Shenley, \\ Radlett, Herts WD7 9HQ
}

SUMMARY A family with Pfeiffer's syndrome is presented in which members of two generations showed only partial but relevant syndactyly before a child was born, in the third generation, with the full acrocephalosynd scty'y syndrome.

The acrocephalosyndactyly syndromes are a group of hereditary disorders which manifest with anomalies of the cranium, hands, and feet. As with other dominantly inherited syndromes the clinical picture varies considerably and this has led to conflicting views about the classification of the acrocephalies. Most authors recognise Apert's, Pfeiffer's and Chotzen's syndromes and there is uncertainty about

*Also at the Division of Inherited Metabolic Diseases, Clinical Research Centre, Northwick Park Hospital, Watford Road, Harrow, Middlesex HA1 3UJ.

Received for publication 7 November 1979 a fourth entity with features of both Apert's and Crouzon's syndrome. ${ }^{1}$ The acrocephalic syndrome of Carpenter can be distinguished because of the presence of polydactyly. ${ }^{2}$ Others have documented the presence of Apert's, Pfeiffer's, and transitional syndromes in multiple generations of the same family suggesting that the subdivision is spurious. ${ }^{3-5}$ The variable expression and improvement of the craniofacial deformities with age has also led to difficulties in detecting minimal manifestations, thereby increasing the possibility of missing gene carriers and counselling incorrectly.

The following report of a family (fig 1) with
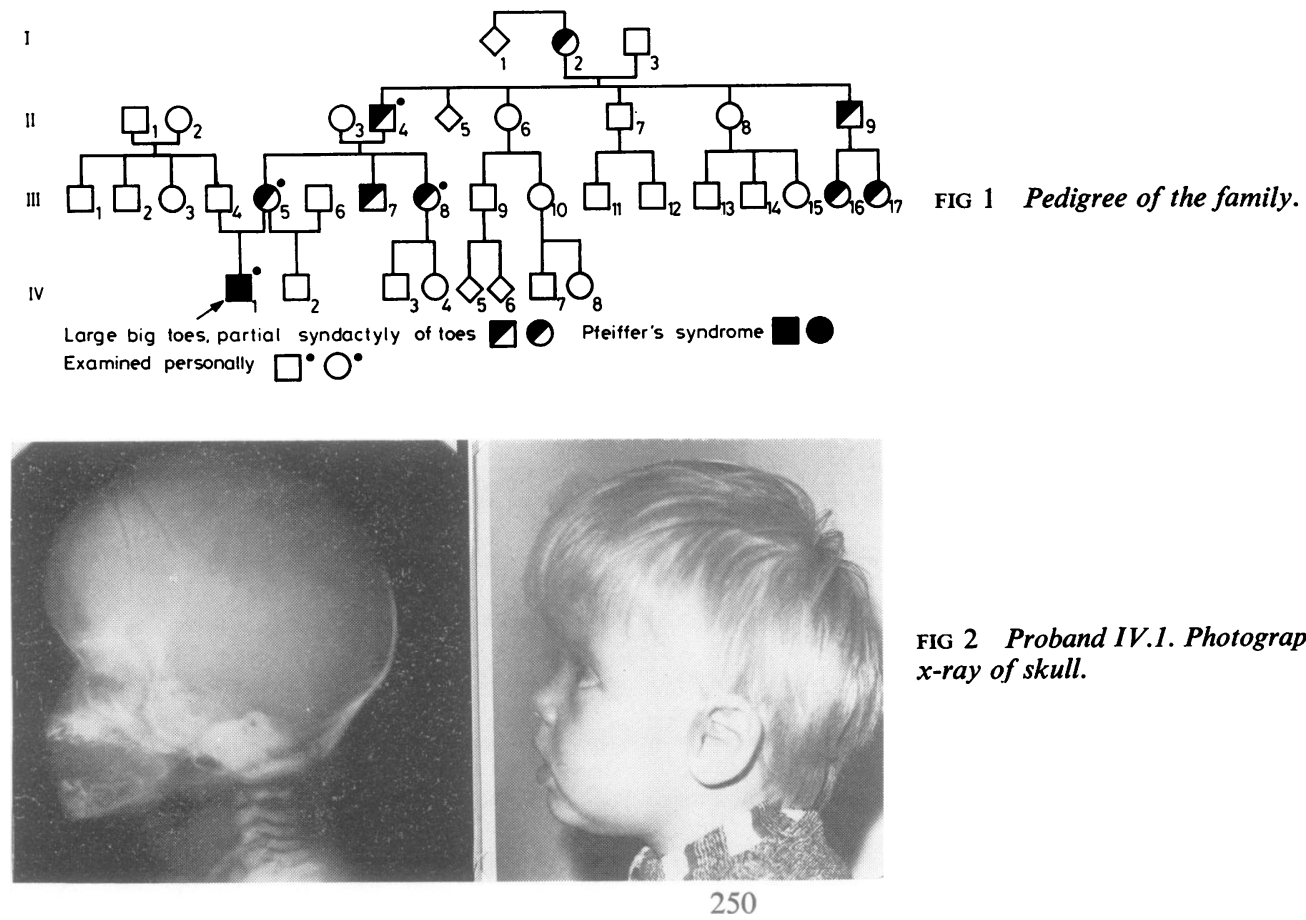

FIG 2 Proband IV.1. Photograph and $x$-ray of skull. 


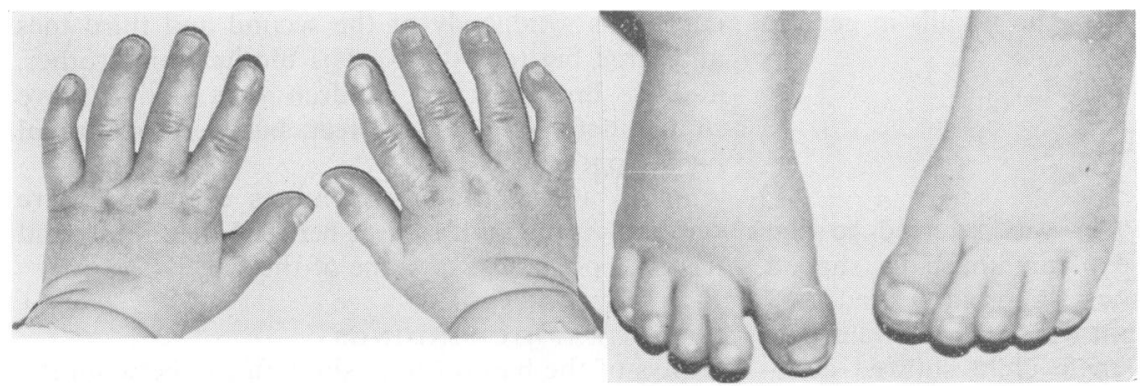

(a)

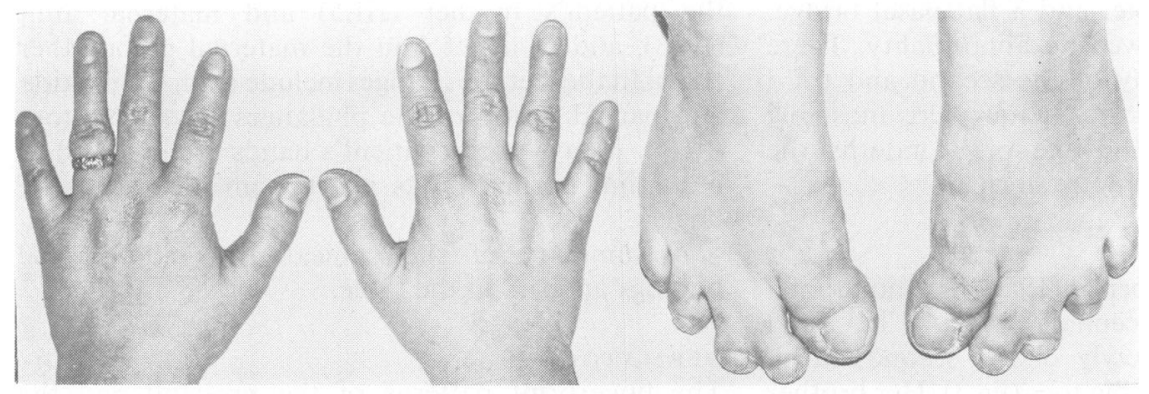

(b)

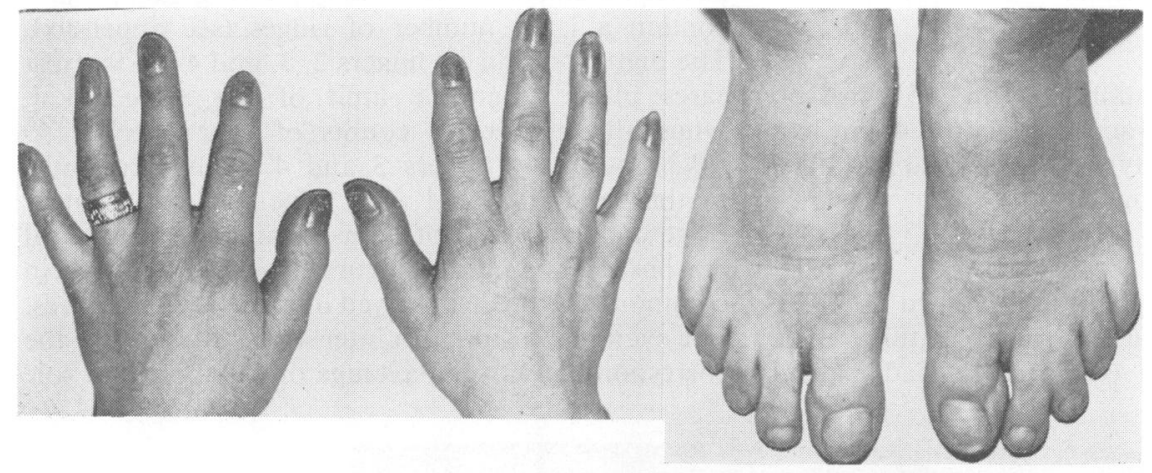

(c)

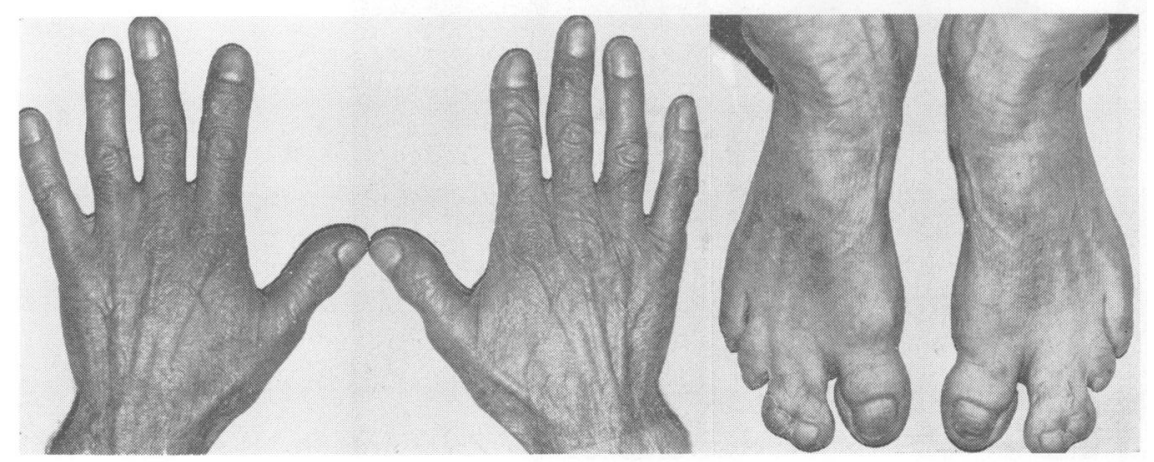

$(d)$

FIG 3 Photographs of hands and feet of (a) IV.1, (b) III.5, (c) III.8, (d) II.4. 
Pfeiffer's syndrome illustrates the pitfalls in genetic counselling.

\section{Case reports}

CASE IV.1

The patient, born in 1977, was referred to the counselling clinic because of an unusually shaped skull (fig 2). The pregnancy was complicated at 3 months by loss of blood but was otherwise uneventful. Examination of the male child showed acrocephaly, hypertelorism, antimongoloid slant of the eyes, a high arched palate, and a flat nasal bridge. The patient's hands showed no abnormality. There was cutaneous syndactyly of the second and third toes bilaterally (fig 3 ) and the big toes were unusually broad. When seen at the age of 9 months the developmental milestones were normal.

\section{CASE III. 5}

The patient's mother, born in 1954, had no cranial manifestations of acrocephaly (fig 4) but had partial cutaneous syndactyly of the second, third, and fourth toes and large big toes (fig 3). Her brother is said to be similarly affected.

\section{CASE III.8}

The patient's maternal aunt, born in 1951, had no cranial manifestations of acrocephaly (fig 4) but had partial cutaneous syndactyly of the second and third toes and large big toes (fig 3).

CASE II. 4

The patient's maternal grandfather, born in 1920, had a high forehead but his facial features were otherwise unremarkable (fig 4). He had partial cutaneous syndactyly of the second and third toes $\frac{\mathbb{D}}{\overparen{D}}$ and large big toes (fig 3). His mother, his brother, $\stackrel{\mathscr{C}}{-}$ and his brother's two children were said to have $\overrightarrow{\vec{F}}$ similar deformities of the feet, but were of normal facial appearance.

In all affected family members examined there $\frac{\bar{c}}{\bar{c}}$ were no visible joint creases between the middle and $\overrightarrow{\vec{\sigma}}$ terminal phalanges of some of the fingers.

\section{RADIOGRAPHIC FINDINGS}

$X$-rays of the hands (fig 5) show fusion between the middle and terminal phalanges of fingers 2 and 5 in $\vec{\omega}$ the patient's mother (III.5) and maternal aunt (III.8), and of finger 1 in the maternal grandfather: (II.4). In the feet the changes include medial deviation $\overrightarrow{\mid}$ and partial fusion of the phalanges of the big toes $A$ (fig 5). $X$-rays of the patient's hands are reported to in be within normal limits apart from incurved little 0 fingers.

A summary of the clinical and radiographic findings appears in the table.

\section{DERMATOGLYPHS}

The fingerprint patterns of the proband and the $\vec{\varphi}$ affected members of his family are of great size and ${ }^{\circ}$ contain a large number of ridges (see appendix) The digital triradii on fingers 2,3 , and 4 are in most 0 cases placed near the limit of the ridged skin. Unusually high ridge counts of near or over 40 을 ridges occur on fingers 3 and 4 in the proband's $\frac{\otimes}{\odot}$ mother and maternal aunt. The proband's finger $\cong$ ridge counts could not be ascertained for technical $\overrightarrow{\vec{O}}$ reasons. His plantar configurations show features in 3 common with those observed in his affected relatives. For example, his pattern intensity (3.0) is above the corresponding normal average of $2 \cdot 8$ loops per sole

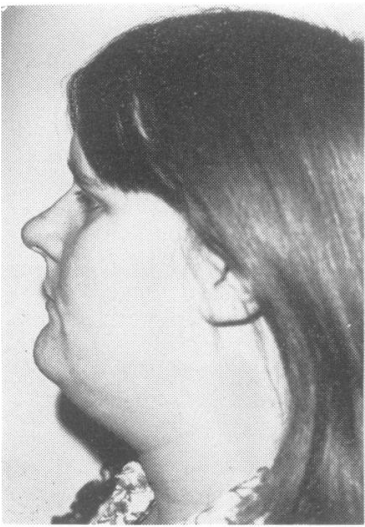

(a)

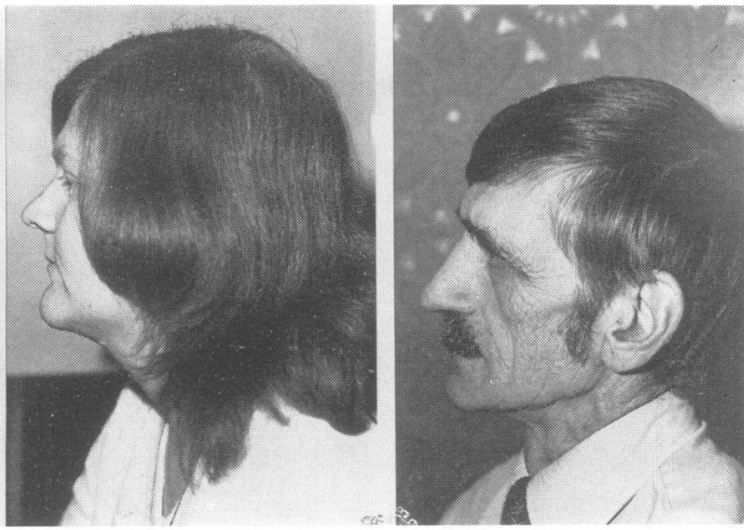

(b) (c)

FIG 4 (a) Mother of proband, (b) maternal aunt, (c) maternal grandfather. 


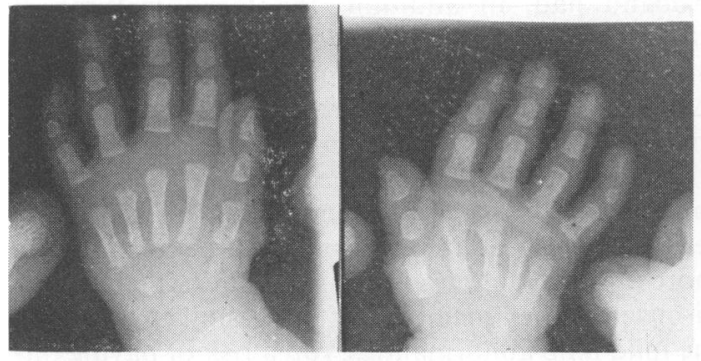

(a)

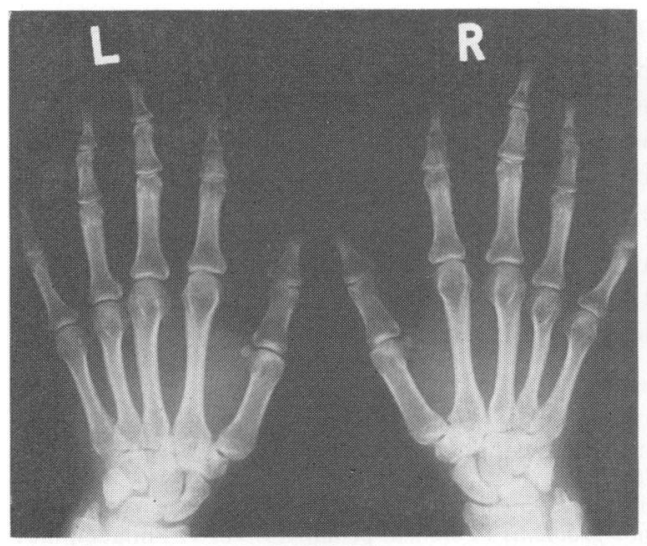

(c)

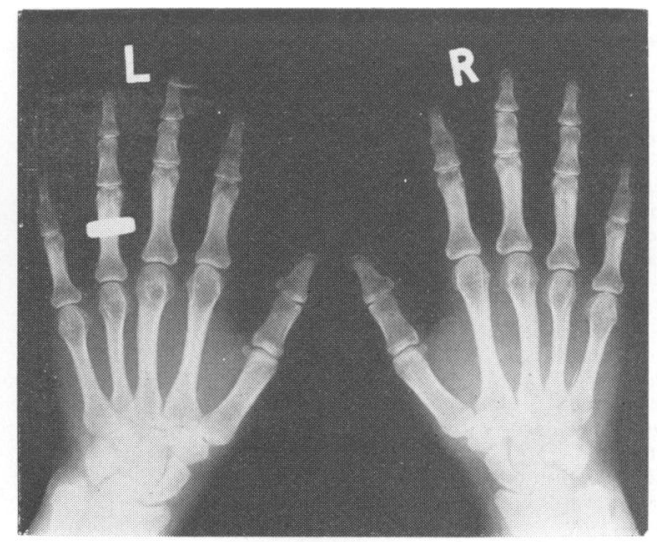

(b)

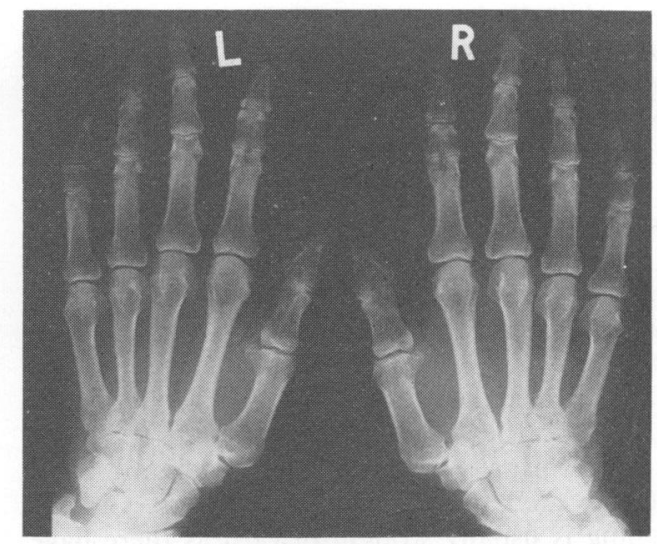

(d)

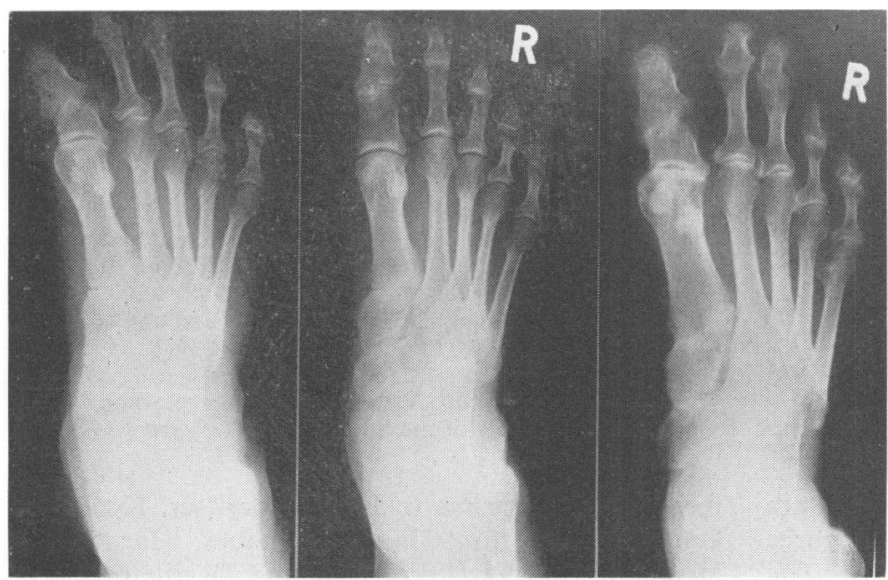

FIG $5 X$-rays of hands and feet of (a) IV.I (hands only, permission withheld for $x$-ray of feet ), (b) III.5, (c) III.8, (d) II.4.

(d) 
TABLE Summary of clinical and radiological findings

\begin{tabular}{|c|c|c|c|c|}
\hline & $I I .4$ & III.8 & III.5 & $\mathrm{IV} .1$ \\
\hline \multicolumn{5}{|l|}{ Heud } \\
\hline Acrocephaly & & & & + \\
\hline High forehead & + & & & + \\
\hline Hypertelorism & & & & + \\
\hline \multicolumn{5}{|l|}{ Antimongoloid slant } \\
\hline of eyes & & & & + \\
\hline Flat nasal bridge & & & & + \\
\hline High arched palate & & & & + \\
\hline \multicolumn{5}{|l|}{ Upper limbs } \\
\hline Absent joint creases & + & + & + & \\
\hline Fusion of phalanges & + & + & + & \\
\hline \multicolumn{5}{|l|}{ Lower limbs } \\
\hline Large big toes & + & + & + & + \\
\hline \multirow{2}{*}{\multicolumn{5}{|c|}{$\begin{array}{l}\text { Cutaneous syndactyly } \\
\text { of toes }\end{array}$}} \\
\hline & + & + & + & + \\
\hline $\begin{array}{l}\text { Medial deviation of } \\
\text { phalanges of big }\end{array}$ & & & & \\
\hline toes & + & + & + & $x$-ray not \\
\hline \multicolumn{5}{|l|}{$\begin{array}{l}\text { Partial fusion of } \\
\text { phalanges of big }\end{array}$} \\
\hline toes & + & + & + & \\
\hline
\end{tabular}

and zygodactyly is represented in both feet. His plantar configurations were not found in a sample of 150 English male controls. The dermatoglyphs of the unaffected father differ from those of his son and show nothing remarkable.

\section{Discussion}

Pfeiffer's syndrome is characterised by acrocephaly, normal intelligence, hypertelorism, antimongoloid slant to the eyes, prominent eyes, flat nasal bridge, irregularly placed teeth, soft tissue syndactyly, broad thumbs and toes, brachymesophalangia, ulnar deviation of the proximal phalanx of the thumbs, and radially deviated phalanges of the fingers. Genetic counselling is usually straightforward as there have been at least three families described with three affected in two generations, ${ }^{67}$ and 138 subjects affected in many generations in whom dominant inheritance was the most likely pattern of transmission. ${ }^{4}$ In the large mid-Western Amish kindred reported by Jackson et al ${ }^{4}$ variable expression was found. A total of 88 members and possibly 50 others were affected. All those affected had clinical or radiological abnormalities of the feet, but enlargement of the thumb did not occur. Several members looked clinically normal or had features of Crouzon's disease, but there were radiographic changes in the feet compatible with Pfeiffer's syndrome. Naveh and Friedman ${ }^{8}$ reported a family with affected members in three generations in whom the signs of Pfeiffer's syndrome were confined to the head and feet, sparing the upper limbs.

In the family presented here members were aware of the transmission of webbed toes over three generations, without noticeable acrocephaly. The main deformities were syndactyly of the second and third toes, large big toes, and the inability to flex the terminal phalanges of the fingers. Only the proband had, in addition, the facial features of Pfeiffer's syndrome. The gene carriers in this family showed in common certain unusual dermatoglyphic features, but there is as yet no evidence that they are specific for Pfeiffer's syndrome.

It came as a shock to the mother to learn that there was an association between what had been regarded as a mild familial trait and the cosmetically more unacceptable craniofacial manifestations of this disorder. Other members of this family, with only the mild limb abnormalities, run a risk of having offspring with the full syndrome, but the risk is probably small. Syndactyly of the second and third toes is a common dominantly inherited malformation so that only the presence of large big toes or thumbs would make Pfeiffer's syndrome a possibility.

\section{Addendum}

The possibility that separate genes are responsible for the limb and craniofacial abnormalities is made less likely by a recent encounter with a second family showing the same variation in expression as the family described above.

The authors thank Dr M A C Ridler for his help with the preparation of this article and Mrs Helen Butcher for typing the manuscript.

\section{References}

1 McKusick VA. Mendelian inheritance in man. 5th ed. Baltimore and London: John Hopkins University Press, 1978:7-8.

2 Smith DW. Recognizable patterns of human malformation. Major problems in clinical pediatrics. vol 7. Philadelphia Saunders, 1976:238-9.

3 Robinow M, Sorauf TJ. Acrocephalopolysyndactyly, type Noack, in a large kindred. Birth Defects 1975;11: 99-106.

4 Jackson CE, Weiss L, Reynolds WA, Forman TF Petersen JA. Craniosynostosis, midfacial hypoplasia and foot abnormalities: an autosomal dominant phenotype in a large Amish kindred. J Pediatr 1976;88:963-8.

5 Escobar V, Bixler D. The acrocephalosyndactyly syndrome: a metacarpophalangeal pattern profile analysis. Clin Genet 1977;11:295-305.

- Martsolf JT, Cracco JB, Carpenter GG, O'Hara AE Pfeiffer syndrome: an unusual type of acrocephalosyndactyly with broad thumbs and great toes. Am J Dis Child $1971 ; 121$ :257-62.

7 Saldino RM, Steinbach HL, Epstein CJ. Familial acrocephalosyndactyly (Pfeiffer syndrome). $A J R$ 1972;116: 609-22.

8 Naveh Y, Friedman A. Pfeiffer syndrome: report of a family and review of the literature. J Med Genet 1976;13: 227-80.

Requests for reprints to Dr M Baraitser, KennedyGalton Centre for Clinical Genetics, Harperbury Hospital, Harper Lane, Shenley, Radlett, Herts WD7 9HQ. 
APPENDIX Dermatoglyphs of the family. (a) IV.I; (b) III.5; (c) III.4; (d) III.8; (e) II.4.
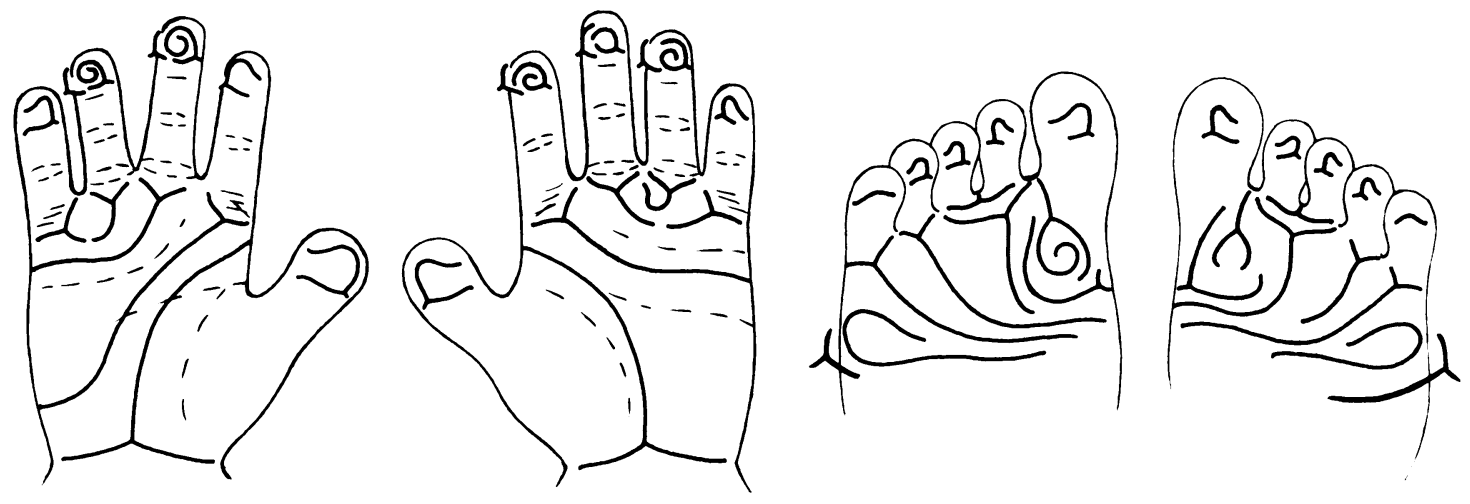

(a)
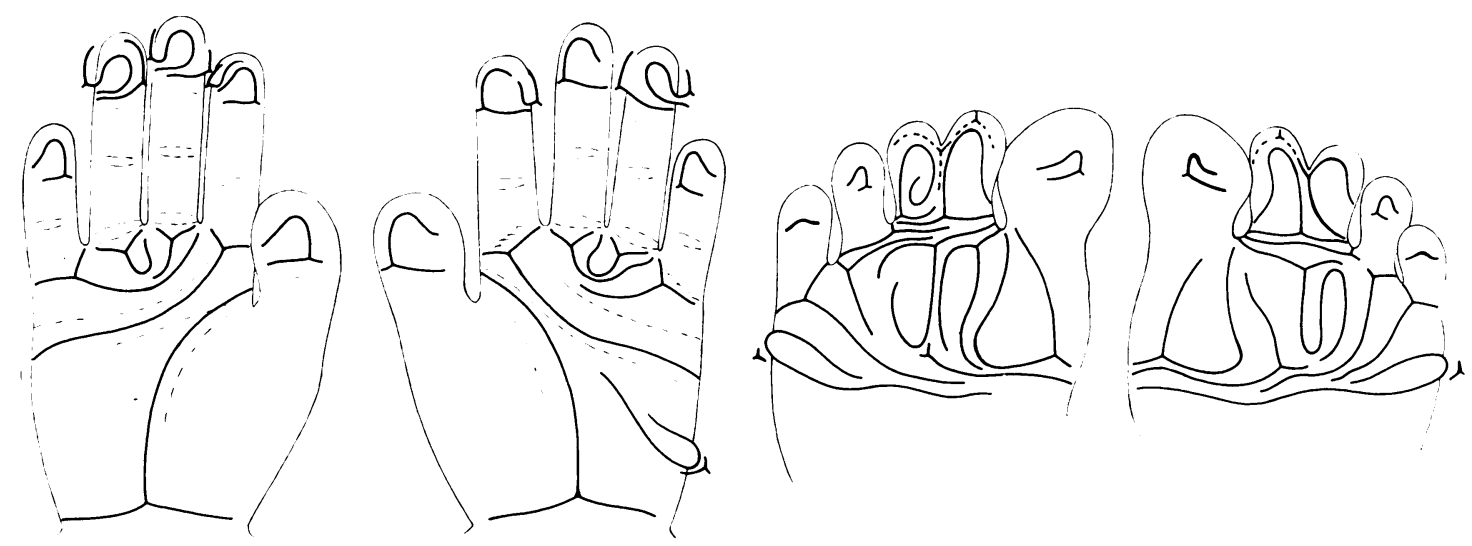

(b)
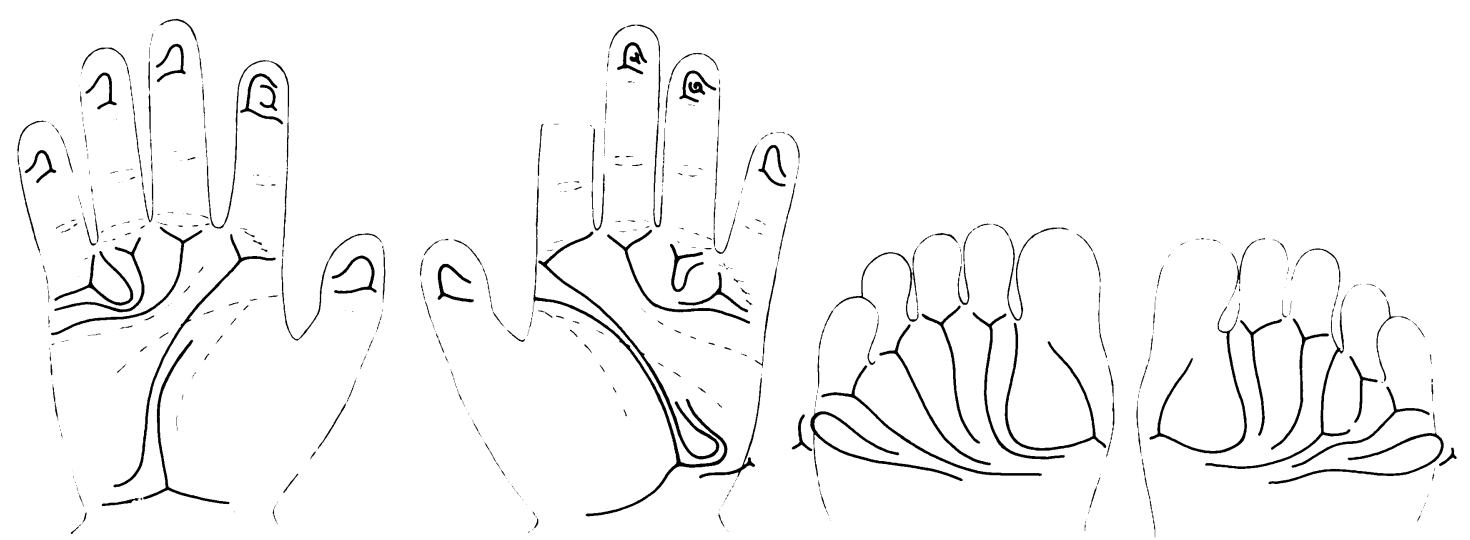

(c) 
256

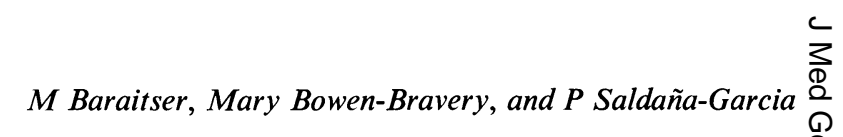
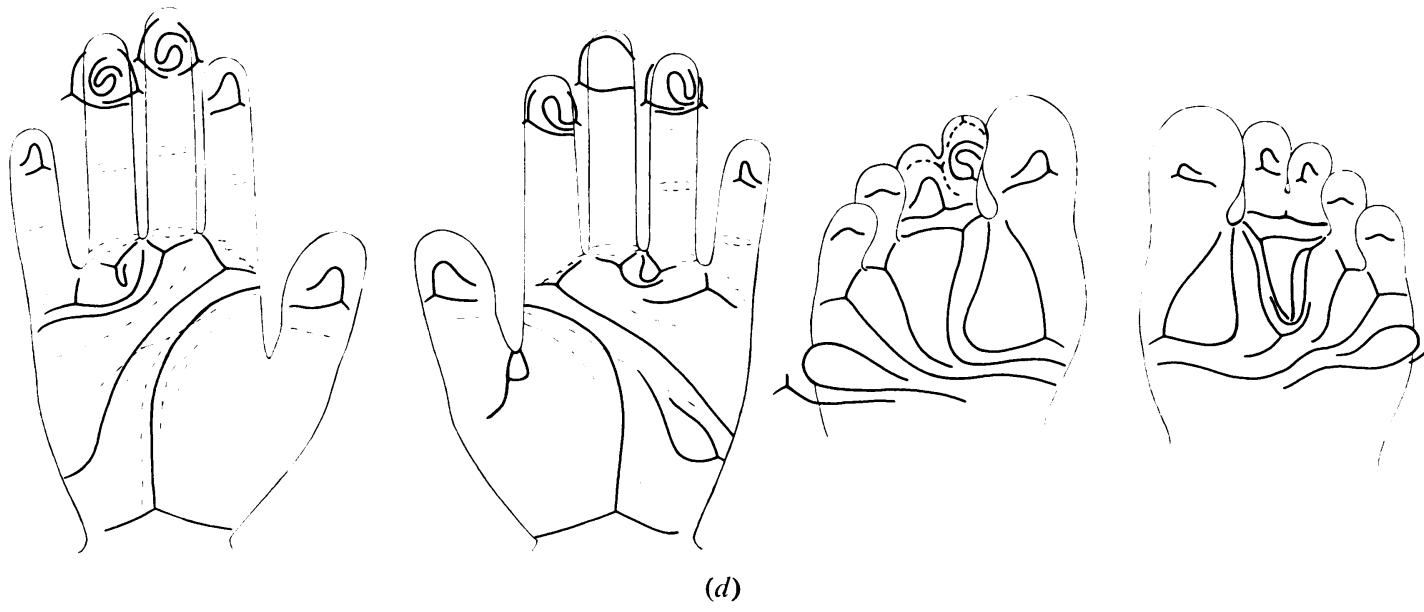

(d)
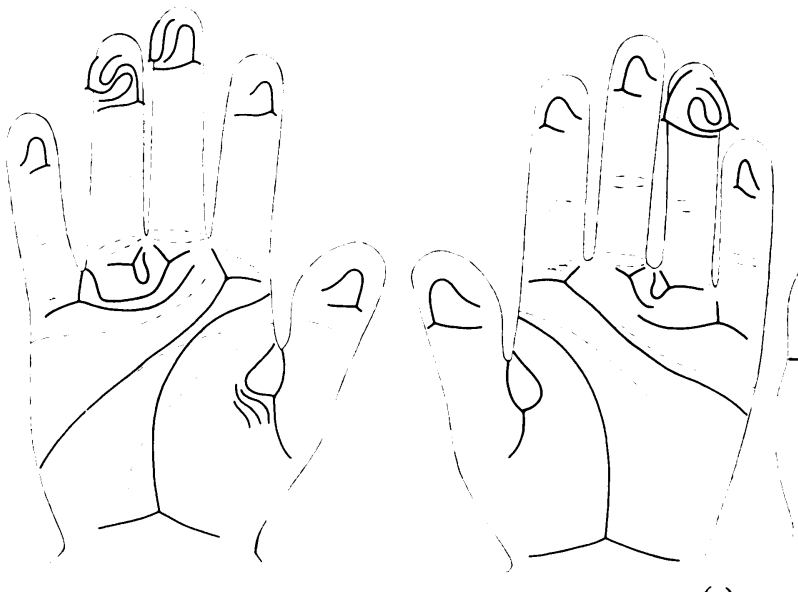

(e)

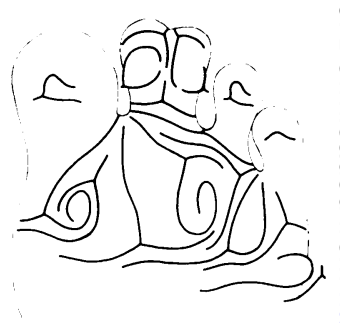

